\title{
The effect of the climate's elements on the sun radiation in Babylon for 2013
}

\author{
Salar Hussein Ibrahem*, Muneer Abdullah Mohammed \\ Department of Physics, College of Education for Pure Sciences, University of Babylon \\ *Corresponding author E-mail: iomneya_11@yahoo.com
}

Copyright () 2015 Ibrahem and Mohammed. This is an open access article distributed under the Creative Commons Attribution License, which permits unrestricted use, distribution, and reproduction in any medium, provided the original work is properly cited.

\begin{abstract}
In this study special equations had used for calculation the quantity of the solar radiation which incident perpendicular on the Babylon city, the benefit of this study is exploitation the solar energy by solar cell to get the electricity.

The data of the weather from the meteorological station in College of Education for pure sciences contains the information of the Monthly average of the Solar Radiation with absence atmosphere $\mathrm{H}_{0}\left(\mathrm{MJ} / \mathrm{m}^{2}\right.$. day), the Monthly Average of the theoretical solar radiance (hr) and Relative Air Mass M(z) from 1/ January / 2013 to 31/ August / 2013. The results of this study explains the effects of the climate's elements (degree of temperature and the relative of humidity), on the solar Radiation. In this study I will discover that we can transform the solar radiation in the Babylon city to the electricity by using the solar cells.
\end{abstract}

Keywords: Radiation; Effect; Babylon; Temperature and Relativity.

\section{Introduction}

The Middle East is a great source of solar energy that has not yet been fully exploited the lack of proper meteorological stations specialized for solar radiation has made it hard to study this great amount of energy source in such regions [1] The earliest model used to estimate global radiation from relative sunshine duration only has been developed by [2] and was modified to a more convenient form by [3], through the following relation ;

$\frac{H}{H \circ}=a+b \frac{S}{S_{\max }}$

Where $\left(\frac{H}{H \circ}\right)$ clearness index, $\left(\frac{S}{S_{\max }}\right)$ relative sunshine duration, $(\mathrm{a}, \mathrm{b})$ regression coefficient that are variable from one location to another and from one model to another.

This model has been developed by many researchers such as (Medugu and Yakubu; Paulescu to suit the theoretical measurement of the monthly mean horizontal daily total terrestrial solar radiation $(\mathrm{H})$, according to the environmental of deferent place's and countries, although the model is considered by several researchers to be regression model [4].

Other model has been developed to calculate monthly daily global solar radiation on horizontal surface with metrological data with one or more combinations of weather parameters as the number of parameters increased, the correlation becomes a multiple linear regression [5].

The objective of the present study is to use different models depending on the number of parameters introduced in each model to calculate monthly daily global solar radiation on horizontal surface $\left(\mathrm{H}_{\mathrm{cal}}\right)$ in $\left(\mathrm{MJ} / \mathrm{m}^{2}\right)$ and mach it with the observed monthly daily global solar radiation on horizontal surface $\left(\mathrm{H}_{\mathrm{obs}}\right)$ in $\left(\mathrm{MJ} / \mathrm{m}^{2}\right)$ taken from the metrological station located in (Babylon University / College of Education for pure sciences - Department of Physics) for eight months. 


\section{Results}

\subsection{The data of the weather from the meteorological station in college of education for pure sciences from January to august 2013}

The data of the Solar Radiation of the Babylon city which was obtain from the meteorological station is in my College. We will use this data do the calculations and diagrams. This calculations and diagrams will show information of Solar Radiation in the Babylon city. Look at the table (1).

Table 1: The Data of the Solar Radiation in the Babylon City for Eight Months in 2013

\begin{tabular}{lccc}
\hline $\begin{array}{l}\text { Mont } \\
\text { h }\end{array}$ & $\begin{array}{l}\text { Monthly Average of the Solar Radiation with } \\
\text { absence Atmosphere } H_{0} \\
\left(M J / m^{2} \text { day }\right)\end{array}$ & $\begin{array}{l}\text { Monthly Average of the theoretical } \\
\text { solar radiance } \\
(\mathrm{hr})\end{array}$ & $\begin{array}{l}\text { Relative Air } \\
\text { Mass } M(\mathrm{z})\end{array}$ \\
\hline Januar & 19.64364066 & 10.14784815 & 0.957876263 \\
$\mathrm{y}$ & 24.82763992 & 10.8821888 & 0.857107249 \\
Febru & 32.17738958 & 11.92144922 & 0.762160161 \\
ary & 37.81203181 & 12.83273765 & 0.716604141 \\
March & 41.729454 & 13.68210849 & 0.698956581 \\
April & 42.82640108 & 14.10679653 & 0.696622747 \\
May & 41.21962654 & 13.87697116 & 0.69743467 \\
June & 37.20677834 & 13.11247089 & 0.708612311 \\
July & & & \\
Augus & & & \\
$\mathrm{t}$ & & & \\
\hline
\end{tabular}

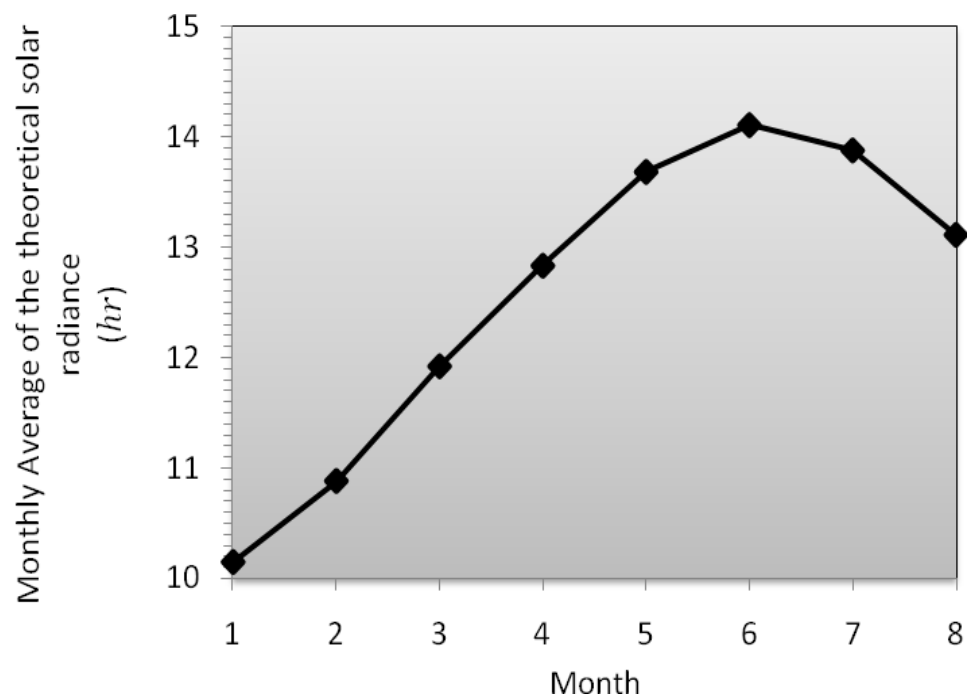

Fig. 1: Diagram of the Monthly Average of the Theoretical Solar Radiance for the Eight Months in Babylon City for 2013.

At the general, the values of the Monthly Average of the theoretical solar radiance in the Babylon city to be distinguished by height in all months especially in May, June and July. But it is slightly low in January and February. The total Average of the theoretical solar radiance in Babylon city is12.57032 $\mathrm{hr}$.

\subsection{The effect of change in temperature and relativity of moistness on the solar radiation}

The quantity of the solar radiation which arriving to any point in the earth is final resultant for any angle of the solar ray and the period of solar radiance therefore there are many of equations which used to expression The quantity of the solar radiation which arriving to the earth [6].

The Angstrom equation is very important equation. It used to calculation the quantity of the solar radiation and the period of solar radiance [6].

$\frac{H_{c a l}}{H_{0}}=a+\left(b \cdot \frac{S}{S_{0}}\right)$

$H_{c a l}$ Is the quantity of the total solar radiation which incident perpendicular on the earth?

, $H_{0}$ is the solar radiation outside the atmosphere.

, $S$ is the period of the practical solar radiance. 
,$S_{0}$ is the period of the theoretical solar radiance.

,$a$ and $b$ is a constants, it is dependent on the place of city.

For the place of Babylon city $a=0.0379$ and $b=0.5389$ these constants has a no unit.

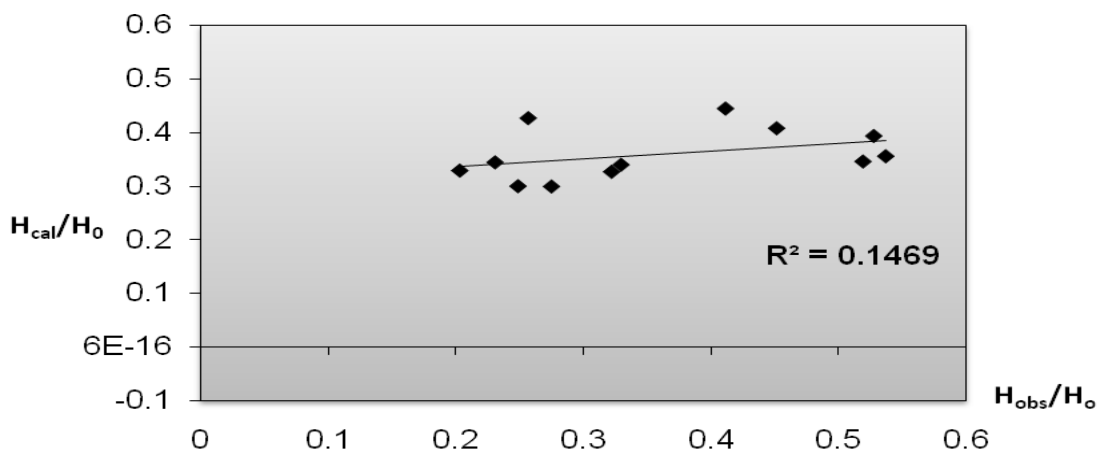

Fig. 2: The Slope between the Relative of the Incidence Solar Radiation in Equation (1) with the Relative of the Absorbent Solar Radiation in the Babylon City in 2013.

When we take the climatic inductions on the incidence solar radiation (degree of temperature and the relative of humidity), we will get the following equations [7], [8], [9]:

$\frac{H_{c a l}}{H_{0}}=0.511+\left(0.664 \frac{S}{S_{0}}\right)-\left(0.013 T_{a v}\right)-\left(0.005 R . H_{a v}\right)$

$\frac{H_{c a l}}{H_{0}}=-0.215+\left(0.516 \frac{S}{S_{0}}\right)+\left(-\frac{3.279}{T_{a v}}\right)+\left(0.015 R . H_{a v}\right)$

$\frac{H_{c a l}}{H_{0}}=1.999+\left(-1.63 \frac{S}{S_{0}}\right)+\left(0.015 T_{a v}\right)+\left(-\frac{30.562}{R . H_{a v}}\right)$

$\frac{H_{c a l}}{H_{0}}=0.208+\left(-0.023 \frac{S}{S_{0}}\right)+\left(\frac{5.651}{T_{a v}}\right)+\left(-\frac{3.768}{R \cdot H_{a v}}\right)$

$\frac{H_{c a l}}{H_{0}}=1.306+\left(0.874 \frac{S}{S_{0}}\right)+\left(-0.021 T_{a v}\right)+\left(-0.006\right.$ R. $\left.H_{a v}\right)+\left(-0.026\left[T_{\max }-T_{\min }\right]\right)$

$\frac{H_{c a l}}{H_{0}}=0.216+\left(0.587 \frac{S}{S_{0}}\right)+\left(-0.011 T_{a v}\right)+\left(0.009 R . H_{a v}\right)+\left(0.004\left[R . H_{\max }-R . H_{\min }\right]\right)$

$\frac{H_{c a l}}{H_{0}}=11.899+\left(1.838 \frac{S}{S_{0}}\right)+\left(-0.165 T_{a v}\right)+\left(-0.161 R . H_{a v}\right)$

$+\left(-0.11\left[T_{\max }-T_{\min }\right]\right)+\left(0.029\left[R . H_{\max }-R . H_{\min }\right]\right)$

And when we sketch the Figures of these equations with the absorbent solar radiation, we will get following Figures (3, $4,5,6,7,8 \& 9)$.

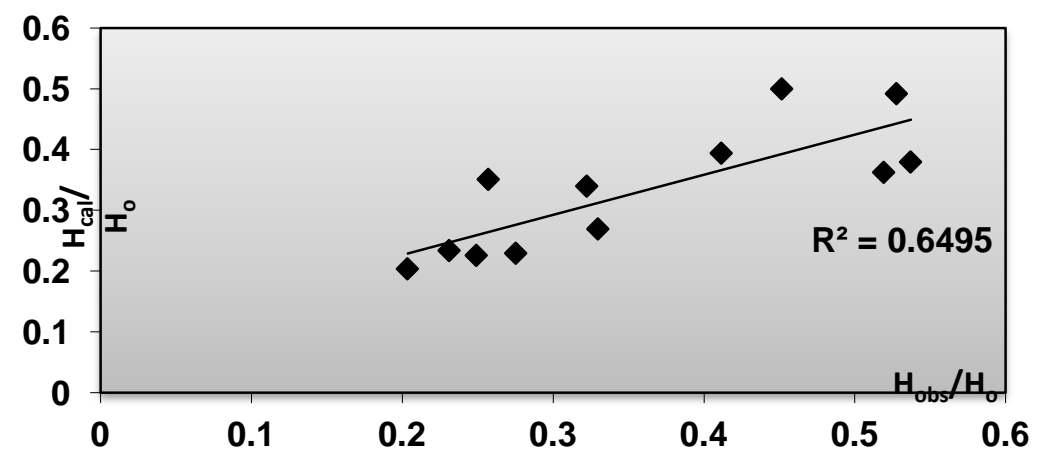

Fig. 3: The Slope between the Relative of the Incidence Solar Radiation in Equation (2) with the Relative of the Absorbent Solar Radiation in Babylon City for 2013.

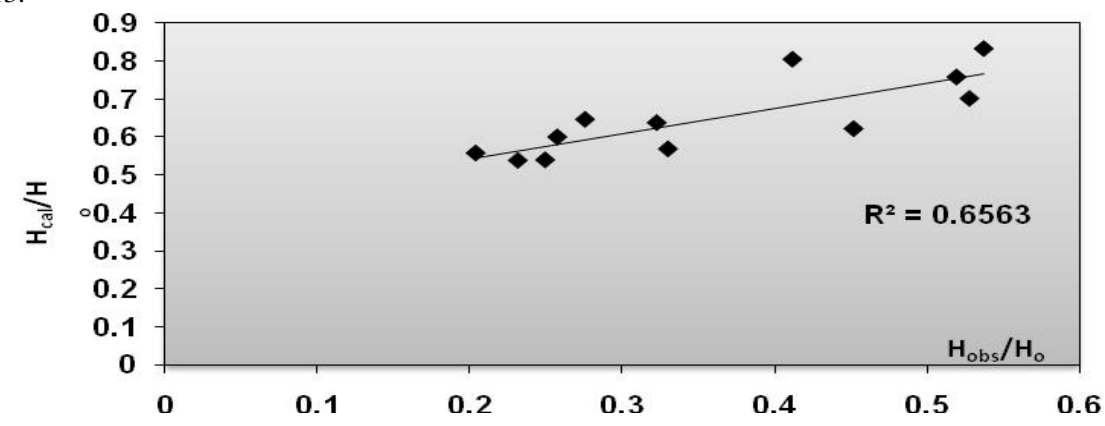

Fig. 4: The Slope between the Relative of the Incidence Solar Radiation in Equation (3) with the Relative of the Absorbent Solar Radiation in Babylon City for 2013. 


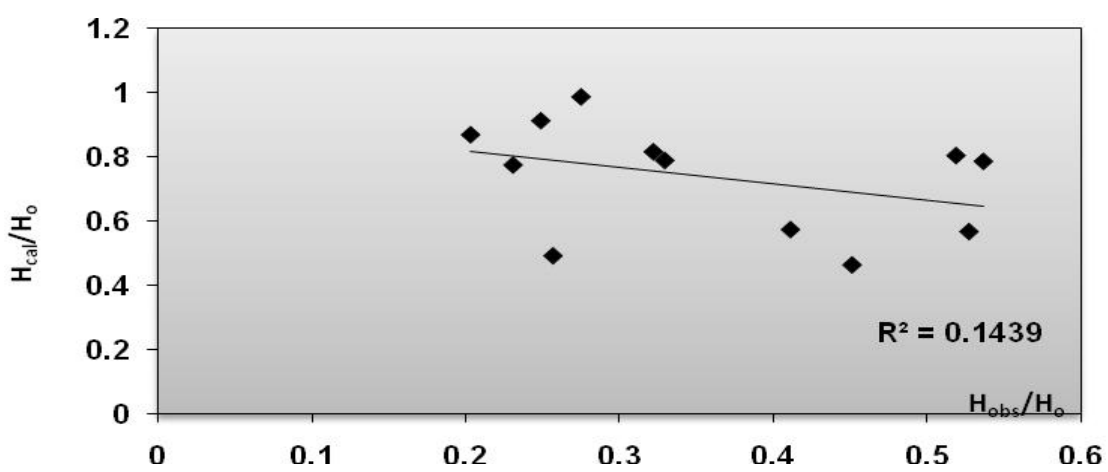

Fig. 5: The Slope between the Relative of the Incidence Solar Radiation in Equation (4) with the Relative of the Absorbent Solar Radiation in Babylon City for 2013.

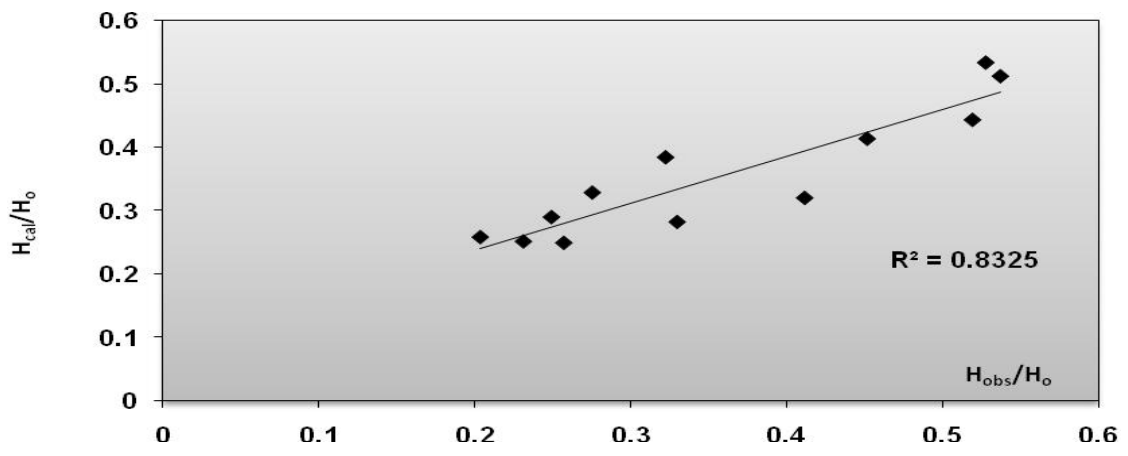

Fig. 6: The Slope between the Relative of the Incidence Solar Radiation in Equation (5) with the Relative of the Absorbent Solar Radiation in Babylon City for 2013.

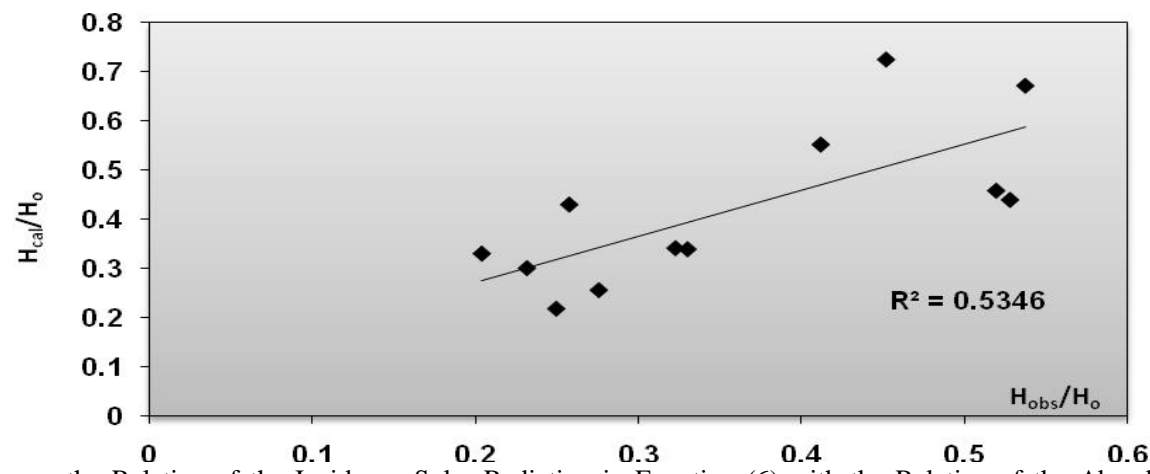

Fig. 7: The Slope between the Relative of the Incidence Solar Radiation in Equation (6) with the Relative of the Absorbent Solar Radiation in Babylon City for 2013.

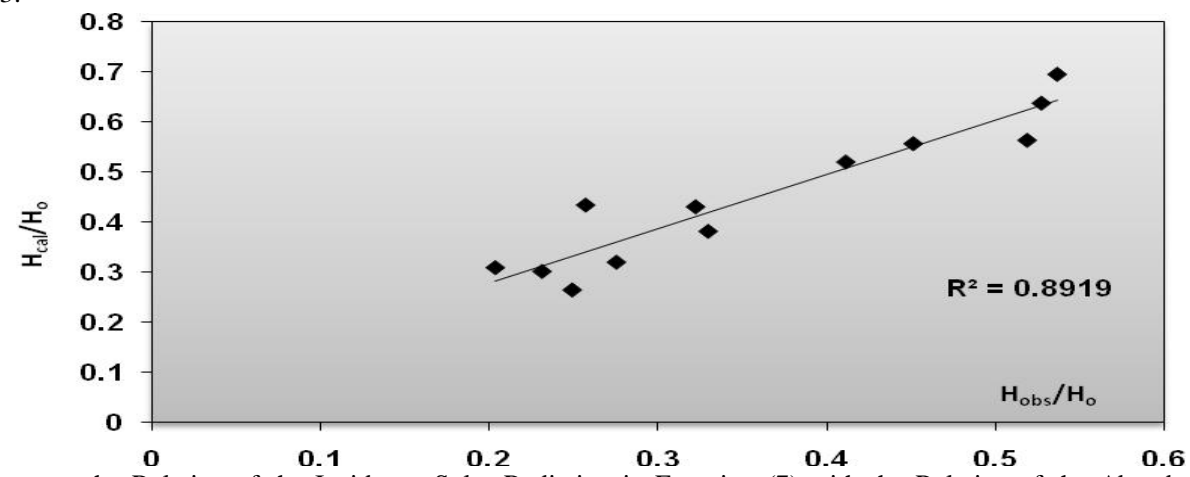

Fig. 8: The Slope between the Relative of the Incidence Solar Radiation in Equation (7) with the Relative of the Absorbent Solar Radiation in Babylon City for 2013. 


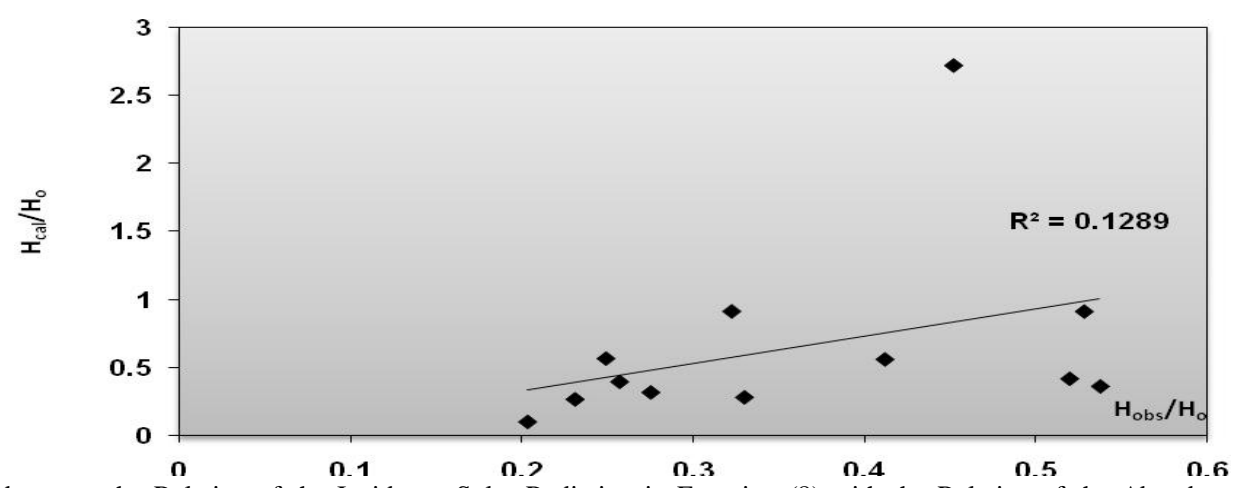

Fig. 9: The Slope between the Relative of the Incidence Solar Radiation in Equation (8) with the Relative of the Absorbent Solar Radiation in Babylon City for 2013.

\section{Discussion}

The average value of the solar radiation in the Babylon city in 2013. Is relative law in the winter and first of the spring (January, February, March and April) but it is high in the summer and last of the spring (May, June, July and August) [3].

In the winter, the average value of the solar radiation is between $\left(19-38 \mathrm{MJ} / \mathrm{m}^{2}\right.$.day), and in the summer it is between $\left(37-43 \mathrm{MJ} / \mathrm{m}^{2}\right.$. day), this is because place of Babylon city in the earth and the angle of the incident solar ray, this angle is inclined in the winter beside the sky is full of clouds and rains and the humidity is high [10].

In the summer, the angle of the incident solar ray is perpendicular, the sky is clean and the humidity is law therefore the average value of the solar radiation is high.

The Monthly average of the solar radiance effects on the solar radiation too, it is between $(10-13 \mathrm{hr})$ in the winter and it is between $(13-14 h r)$ in the summer [11].

\section{Conclusions}

1) The average value of the solar radiation in Babylon city for 2013 . is equal $\left(34.6804 \mathrm{MJ} / \mathrm{m}^{2}\right.$. day), and the monthly average of the solar radiance is equal $(12.57032 \mathrm{hr})$, we can get 400 watt for any meter square of Babylon city in about (12.5 hr) if we get competent solar cell [12]:

$$
34.6804 \frac{\mathrm{MJ}}{\mathrm{m}^{2} \text {. day }}=\frac{34.6804 \times 10^{6} \mathrm{~J}}{\mathrm{~m}^{2} \cdot(24 \times 60 \times 60) \mathrm{sec}} \approx 400 \frac{\mathrm{J}}{\mathrm{m}^{2} \cdot \mathrm{sec}}=400 \frac{\mathrm{watt}}{\mathrm{m}^{2}}
$$

2) From the data of the table (1), when the monthly average of the solar radiance is maximum and the relative air mass is minimum the solar radiation become maximum, and when the monthly average of the solar radiance is minimum and the relative air mass is maximum the solar radiation become minimum.

The maximum average value of the solar radiation is equal $\left(42.8264 \mathrm{MJ} / \mathrm{m}^{2}\right.$. day) in the summer in August and the minimum average value of the solar radiation is equal $\left(19.6436 \mathrm{MJ} / \mathrm{m}^{2}\right.$. day) in the winter in January.

\section{References}

[1] Akpabio, L.E. and Etuk S.E., (2003), "Relationship between global solar radiation and sunshine duration for Onne, Nigeria", Turk J. Phys., Vol.15, P.865

[2] Toğrul, I.T., (1998), "Comparison of statistical performance of seven sunshine-based models for Elazı̆g, Turkey", Chimica Acta Turcica, Vol. 26, P.37.

[3] Prescott, J.A., (1940), "Evaporation from a water surface in relation to solar radiation", Trans Roy Soc Aust., Vol. 64, P.48.

[4] Duffie, J.A. and Beckman W.A., (1994), "Solar Engineering of thermal Processes", 2nd Edn., John Wiley, New York.

[5] Falayi, E.O. and Rabiu A.B., (2005), "Modeling global solar radiation using sunshine duration data Nig.", J. Physics, Vol.17S, P. 181.

[6] Medugu, D. W. and Yakubu D., (2011), "Estimation of mean monthly global solar radiation in Yola - Nigeria", Pelagia Research Library, Vol.2, P.414.

[7] Okundamiya, M.S. and Nzeako A.N., (2011), "Empirical model for estimating global solar radiation on horizontal surfaces for selected cities in the six geopolitical zones in Nigeria", J. of Control Sci. and Eng., Vol.2011, P.7. http://dx.doi.org/10.1155/2011/356405.

[8] Paulescu, M., Fara L. and Tulcan-Paulescu E., (2006), "Model's for obtaining daily global solar irradiation from air temperature data", Atmospheric Research, Vol. 79, P. 227. http://dx.doi.org/10.1016/j.atmosres.2005.06.001.

[9] Skeiker, K., (2006), "Correlation of global solar radiation with common geographical and meteorological parameters for Damascus province", Syria, Energy conversion and management, Vol.47, P. 331. http://dx.doi.org/10.1016/j.enconman.2005.04.012.

[10] Stone, R.J., (1993), "Improved statistical procedure for the evaluation of solar radiation estimation models", Solar Energy,Vol. 51, P.289. http://dx.doi.org/10.1016/0038-092X(93)90124-7.

[11] Toğrul, I.T., (2009), "Estimation of Solar Radiation from Angstroms Coefficients by using Geographical and Meteorological data in Bishkek", Kyrgyzstan, J. Thermal Science and Technology, Vol.29, P.99.

[12] Walpole, R.E. and Myers, R.H., (1989), "Probability and statistics for engineers and scientists", Macmillan, 4th ed, New York. 